\title{
The Main Causes of Absenteeism Disease Among Nursing Professionals - An Integrative Literature Review
}

\author{
Bruno Vilas Boas Dias*1, Amanda Príncipe Pagano², Bruna Guedes Miguel Gomes², Débora Aline de \\ Souza $^{2}$, Maryana Cristina de Souza Marcondes ${ }^{2}$, Michelle Gualassi Zacari ${ }^{2}$ Pamela Ane de Lima Viana ${ }^{2}$, \\ Rebecca Ferronato de Azevedo², Thales Henrique dos Santos ${ }^{2}$ and Rafael Antonio da Silva ${ }^{3}$ \\ ${ }^{1}$ Professor Master of the Undergraduate Course in Nursing, Brazil \\ ${ }^{2}$ Graduating in Nursing, Brazil \\ ${ }^{3}$ Specialist Course in Nursing, Brazil \\ *Corresponding author: Bruno Vilas Boas Dias, Professor master of the Undergraduate Course in Nursing, Brazil
}

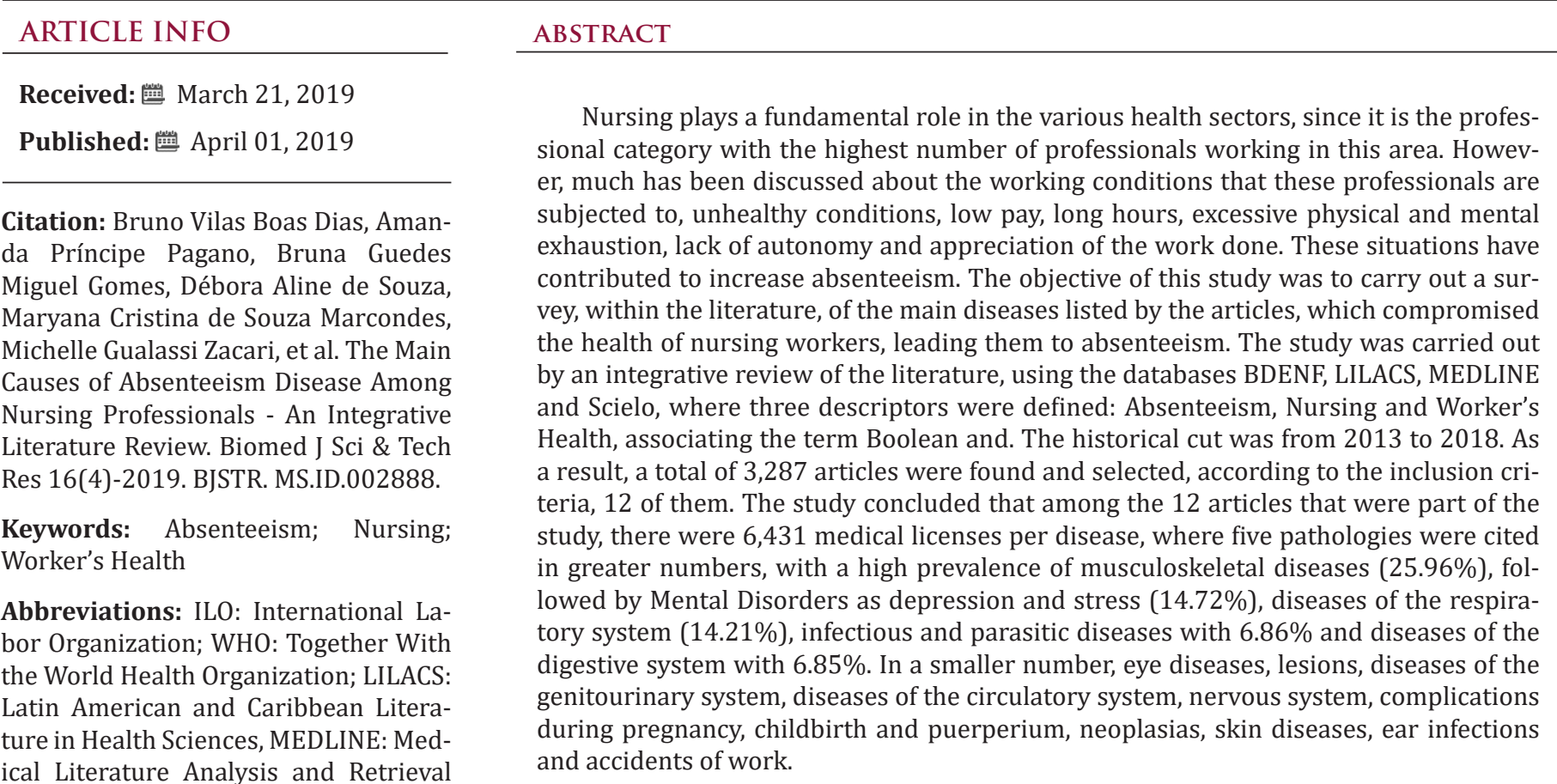
Analysis and Retrieval System Online

\section{Introduction}

Nursing plays a fundamental role in the various health sectors, since it is the professional category with the highest number of professionals working in this field. Faced with this scenario, there are many problems encountered in this field due to the labor demands that arise but are not adequately addressed. The most frequently encountered problems are the overload of work and the work shift in the work schedule, as well as the inadequacy of the nursing staff, which are the major risk factors for the health of the professional and also for patient safety [1]. In the hospital, the nursing team suffers the most from the unhealthy environment. All of these factors contribute to job failure [2]. These absences at work are translated by absenteeism, a word of French origin (absenteeism) which means lack of attendance at work. Absenteeism is an expression used to denote the worker's absence 
from work activities not motivated by unemployment, prolonged illness or legal leave [3]. The absenteeism is the frequency or duration of work time lost when professionals do not attend work and absences correspond when they are expected to be present. Misconduct leave of absence for participation in training and development programs, among others, constitute absences [4].

Absenteeism is classified into five types: absenteeism-illness (absence justified by health leave); absenteeism due to professional pathology (occupational accidents and/or occupational disease); legal absenteeism (supported by laws such as gestation, disgust, gala, blood donation and military service); compulsory absenteeism (suspension imposed by the employer, imprisonment or other impediment to attend work); and voluntary absenteeism (unjustified private reasons) [5]. Faced with this classification, the absenteeism due to illness, which refers to removal from medical certificates, is the main cause of non-programmed work absences, reaching 71 to $81 \%$ of the total. These high levels of absenteeism are disruptive and bring major losses, for example, the annual cost of absenteeism to the UK national economy was estimated at about $£ 1.5$ billion in 2013. In Brazil, a nursing worker from a single hospital in São Paulo in 2008 showed that absenteeism-illness cost the employer equivalent to $\mathrm{R} \$ 389.817,76$ referring to the 2,538 days of absences in a year. These financial charges cause damage to the service and to the workers, be it in the economic, operational, physical and mental order, with decreasing productivity, cost increases, job dissatisfaction and overloading of other health workers [6].

The nursing is the profession that suffers most from illness, being more subject to the effects of stress than other professions. Because of this, there is growing concern on the part of government agencies and researchers about the working conditions of health professionals, especially nursing, since both the working conditions and the environment in which it is exercised, in general, does not always provide effective safety for workers. Among these nursing professionals, absenteeism should receive special attention due to the characteristics of the work and to directly influence the quality of care provided [7]. Through this, since the 1930s, the International Labor Organization (ILO), together with the World Health Organization (WHO), work with studies that have identified the precarious situation of the work of nursing professionals. The focus of these studies has been the unsatisfactory conditions of nursing work, due to long hours of work, absence of rest periods, on Sundays and holidays without fair compensation, and lack of participation in planning and decision-making in relation to nursing. professional practice, teaching and working conditions [8]. Faced with this problematic that surrounds the difficult working conditions of nursing professionals, and justifies our choice for this subject, it becomes imperative to understand what are the main diseases that are compromising the health of these workers and that are resulting in increased absenteeism. Whereas, emphasizing the results found, it will enable the search for solutions that will improve the quality of life and health of these professionals.

\section{Objective}

To carry out a survey, within the literature, of the main diseases listed in the articles, which compromised the health of nursing workers, leading them to absenteeism.

\section{Method}

Integrative literature review. For the bibliographic survey, the electronic databases were used: Nursing Database (BDENF), Latin American and Caribbean Literature in Health Sciences (LILACS), Medical Literature Analysis and Retrieval System Online (MEDLINE) and virtual health library Scientific Electronic Libary On Line (Scielo).Three descriptors were defined: Absenteeism, Nursing and Worker Health, associated with the Boolean operator "AND". The research was carried out in the first and second semester of 2018, obeying the inclusion criteria: articles published in Portuguese between 2013 and 2018; available in the databases consulted and in full text. The exclusion criteria adopted were: bibliographic review articles; editorials; abstracts, dissertations and theses.

\section{Result}

(Table 1) shows the descriptors used, databases, number of articles found and articles selected, according to an integrative review of the literature. And (Chart 1) presents the articles in relation to the base, year, author, theme and conclusion. After analyzing the 12 articles selected to be part of this study, the diseases that most caused absenteeism among the nursing team were raised in relation to the number of sick leave, as shown in Table 2 .

Table 1: Relation of the association of the descriptors used, databases, number of articles found and articles selected.

\begin{tabular}{|c|c|c|c|}
\hline Descriptors & Base & Articles Found & Selected Articles \\
\hline Absenteeism and Nursing & Scielo & 48 & 2 \\
\hline Absenteeism and Worker's health & Scielo & 34 & 0 \\
\hline Worker's health and Nursing & Scielo & 357 & 5 \\
\hline Absenteeism and Nursing & Lilacs & 128 & 0 \\
\hline Absenteeism and Worker's health & Lilacs & 203 & 2 \\
\hline Worker's health and Nursing & Lilacs & 1.715 & 0 \\
\hline Absenteeism and Nursing & Medline & 705 & \\
\hline
\end{tabular}




\begin{tabular}{|c|c|c|c|}
\hline Absenteeism and Worker's health & Medline & 0 \\
\hline Worker's health and Nursing & Medline & 0 & 0 \\
\hline Absenteeism and Nursing & Bdenf & 0 & 0 \\
\hline Absenteeism and Worker's health & Bdenf & 0 & 0 \\
\hline Worker's health and Nursing & Bdenf & 3.287 \\
\hline Total & & 0 \\
\hline
\end{tabular}

Chart 1: List of articles according to the database, year, author, theme and conclusions.

\begin{tabular}{|c|c|c|c|}
\hline Base & Year/Author & Theme & Conclusion \\
\hline BDENF & Moisés et al. [7] & $\begin{array}{l}\text { Main causes of absenteeism in } \\
\text { nursing professionals. }\end{array}$ & $\begin{array}{l}\text { Among the } 17 \text { interviewees who were absent due to personal illness, } 5 \text { were } \\
\text { due to stress, } 2 \text { due to musculoskeletal problems, } 1 \text { due to work accident } 9 \text { due } \\
\text { to other problems such as chronic renal failure, dengue, pharyngitis, ovary cyst, } \\
\text { pneumonia, conjunctivitis and abdominal pain. }\end{array}$ \\
\hline Lilacs & Trindade et al. [14] & $\begin{array}{l}\text { Absenteeism in the nursing team in } \\
\text { the hospital environment. }\end{array}$ & $\begin{array}{l}\text { Of the } 1,378 \text { interviewees, } 405 \text { different diseases were found that led the } \\
\text { professionals to absenteeism, in which parasitic diseases prevailed with } 4 \% \text {, } \\
\text { musculoskeletal diseases with } 2.8 \% \text { and depressive episodes with } 1.8 \% \text {. }\end{array}$ \\
\hline Lilacs & Rodrigues et al. [9] & $\begin{array}{l}\text { Absenteeism of nursing } \\
\text { professionals from a university } \\
\text { hospital in the state of São Paulo, } \\
\text { Brazil. }\end{array}$ & $\begin{array}{c}\text { Among the } 4,049 \text { professionals interviewed who were absent for health } \\
\text { reasons, diseases of the musculoskeletal system prevailed with } 20.97 \% \text {, } \\
\text { followed by diseases of the respiratory system with } 11.7 \% \text {, mental disorders } \\
\text { with } 8.90 \% \text {, diseases of the device digestive disease with } 8.37 \% \text { and infectious } \\
\text { or parasitic infections with } 6.25 \% \text {. }\end{array}$ \\
\hline Lilacs & $\begin{array}{l}\text { Mantovani et al. } \\
\text { [13] }\end{array}$ & $\begin{array}{l}\text { Absenteeism due to illness in } \\
\text { nursing professionals. }\end{array}$ & $\begin{array}{l}\text { The main reasons for sick leave in the study population prevailed } \\
\text { musculoskeletal diseases and respiratory diseases. }\end{array}$ \\
\hline Scielo & Marques et al. [11] & $\begin{array}{l}\text { Absenteeism - illness of the nursing } \\
\text { team of a university hospital. }\end{array}$ & $\begin{array}{c}\text { A total of 1,574 professionals were interviewed, with a prevalence of } \\
\text { musculoskeletal and connective tissue diseases at } 19.70 \% \text {, followed by mental } \\
\text { disorders with } 18.04 \% \text {, respiratory diseases with } 6.35 \% \text {, diseases of the } \\
\text { digestive system with } 5.02 \% \text { and diseases infectious and parasitic diseases } \\
\text { with } 2.48 \% \text {. }\end{array}$ \\
\hline BDENF & Gonçalves et al. & $\begin{array}{c}\text { Absenteeism - Disease: its relation } \\
\text { with the nursing team of the Colíder } \\
\text { Regional Hospital. }\end{array}$ & $\begin{array}{l}\text { A total of } 266 \text { leave / sick leave were consulted, with musculoskeletal diseases } \\
\text { accounting for } 35.30 \% \text {, followed by mental disorders with } 15.60 \% \text {, diseases of } \\
\text { the genitourinary system with } 8.38 \% \text {, respiratory diseases with } 5,92 \% \text { and } \\
\text { diseases of the digestive system with } 2.40 \% \text {. }\end{array}$ \\
\hline Lilacs & Heylmann et al. & $\begin{array}{l}\text { Absenteeism among nursing } \\
\text { professionals: study in a university } \\
\text { hospital in Santa Catarina. }\end{array}$ & $\begin{array}{l}\text { Of the } 136 \text { interviewees, there was a prevalence in the number of departures } \\
\text { from eye diseases and adnexa with } 21.32 \% \text {, accompanied by diseases of } \\
\text { the musculoskeletal system with } 19.11 \% \text {, diseases of the respiratory tract } \\
\text { with } 14.07 \% \text {, diseases of the genito-urinary tract with } 7.35 \% \text {, infectious and } \\
\text { parasitic diseases with } 7.35 \% \text {. }\end{array}$ \\
\hline Scielo & Quadros et al. & $\begin{array}{l}\text { Analysis of managerial and } \\
\text { assistance indicators after the } \\
\text { adequacy of nursing personnel. }\end{array}$ & $\begin{array}{l}\text { A total of } 308 \text { professionals were interviewed, of which } 25 \% \text { were mental } \\
\text { disorders, } 16.60 \% \text { were dorsopathies, } 8.9 \% \text { were respiratory system diseases, } \\
7.1 \% \text { were gestational complications and } 0.7 \% \text { were diseases of the genital } \\
\text { system-urinary. }\end{array}$ \\
\hline BDENF & Vasconcelos et al. & $\begin{array}{l}\text { Absenteeism in two public hospitals } \\
\text { in Minas Gerais: epidemiological } \\
\text { profile. }\end{array}$ & $\begin{array}{l}\text { A total of } 309 \text { licenses for diseases were analyzed, } 76 \text { cases of mental disorders, } \\
56 \text { cases of conjunctivitis, } 60 \text { cases of sinusitis, } 28 \text { cases of hypertension, } 51 \\
\text { cases of soft tissue disorders and } 38 \text { cases of diarrhea. }\end{array}$ \\
\hline Lilacs & Varges Barbosa & $\begin{array}{l}\text { Factors related to the removal of } \\
\text { nurses from a public hospital in the } \\
\text { city of Vitória da Conquista. }\end{array}$ & $\begin{array}{l}\text { Considering a total of } 146 \text { certificates, } 15.8 \% \text { were diseases of the respiratory } \\
\text { system, } 11 \% \text { of musculoskeletal diseases and } 9.6 \% \text { of diseases of the digestive } \\
\text { system. }\end{array}$ \\
\hline Lilacs & Galindo et al. & $\begin{array}{l}\text { Reasons for absenteeism in an } \\
\text { outpatient nursing team. }\end{array}$ & $\begin{array}{l}\text { Of the } 23 \text { sick leave analyzed, } 52.5 \% \text { were caused by musculoskeletal diseases, } \\
26 \% \text { were mental disorders, } 13 \% \text { were diseases of the circulatory system, } 4.3 \% \\
\text { were infectious and parasitic, and } 4.1 \% \text { were due to surgeries. }\end{array}$ \\
\hline Lilacs & Silva et al. & $\begin{array}{c}\text { Absenteeism in the nursing team in } \\
\text { a hospital in the interior of Minas } \\
\text { Gerais. }\end{array}$ & $\begin{array}{l}\text { The highest rates of absenteeism were due to diarrhea, with } 55 \text { certificates, } \\
\text { low back pain, } 25 \text { attestations, sinusitis, } 20 \text { attestations and, finally, depressive } \\
\text { episodes, with } 15 \text { attestations. }\end{array}$ \\
\hline
\end{tabular}


Table 2: Relation between the main diseases that caused absenteeism and the number of sick leave in the nursing team.

\begin{tabular}{|c|c|c|}
\hline Diseases that Cause Absenteeism & Number of Licenses & 25.96 \\
\hline Diseases of osteomuscular and tissue systems & 1,702 & 14.72 \\
\hline Mental Disorders such as Depression and Stress & 965 & 14.21 \\
\hline Respiratory system diseases & 932 & 6.86 \\
\hline Infectious and parasitic diseases & 450 & 6.85 \\
\hline Diseases of the digestive system & 449 & 6.02 \\
\hline Eye diseases and appendages & 395 & 5.73 \\
\hline Injuries and poisonings & 376 & 4.74 \\
\hline Diseases of the genitourinary system & 311 & 4.00 \\
\hline Diseases of the circulatory system & 262 & 2.44 \\
\hline Diseases of the nervous system & 160 & 1.92 \\
\hline Complications during pregnancy, delivery and puerperium & 126 & 1.92 \\
\hline Neoplasms & 126 & 1.48 \\
\hline Disin and subcutaneous tissue disorders & 97 & 0.29 \\
\hline Work accident & 19 & 0.11 \\
\hline Tother diseases not mentioned & 7 & 2.75 \\
\hline
\end{tabular}

\section{Discussion}

Based on the results found, it was verified that in the 12 articles that were part of this study, there were a total of 6,557 medical licenses per disease. According to the data in Table 2, diseases of the musculoskeletal system and tissues were the ones that caused the most absenteeism by disease with $25.96 \%$ of the licenses, followed by mental disorders such as depression and stress that presented $14.72 \%$, diseases of the respiratory system with infectious and parasitic diseases with $6.86 \%$, diseases of the digestive system with $6.85 \%$, ocular diseases and attachments with $6.02 \%$, lesions and poisonings with $5.73 \%$, diseases of the genito- complications during pregnancy, delivery and puerperium with $1.92 \%$, neoplasms with the same $1.92 \%$, diseases of the circulatory system with $4 \%$, diseases of the nervous system with $2.44 \%$ skin and subcutaneous tissue with $1.48 \%$, diseases of the auricular apparatus with $0.29 \%$, work accident with $0.11 \%$ and other diseases that were not pointed out by the works researched corresponded to $2.75 \%$. The group of musculoskeletal diseases was the main cause of absenteeism, according to the survey, corresponding to about a quarter of all licenses. These data reveal physical overload and unsatisfactory ergonomic conditions in the performance of the work.

The nursing team, during the work activities, helps the patient move in and out of the bed. As coworkers move away, there is overhead for others in a situation of continuous demand. Inadequate posture is another aggravating factor, which is associated with psychic load. In addition, the incidence of complaints has a greater impact on women, due not only to the biological characteristics of women, but also to the unequal division of sex at work today. Other causes are associated with overtime, work pace and working conditions [9]. Besides that, the musculoskeletal disorders are the most common cause of withdrawal. In a study cited by him, it was shown that 80 to $93 \%$ of the occurrences of musculoskeletal disorders are associated with the nursing work conditions in the hospital setting. The regions most affected were the cervical, shoulders and knees, the lumbar region being the most evident [10]. Mental disorders such as depression and stress were the second major cause of absenteeism. The nursing professional coexists constantly with pain, suffering and death. These conditions can lead you to develop psychiatric illness. With regard to the relationship between stress and work, it is observed that the human being is faced with a professional universe that often makes demands beyond its capacity in contemporary society. This fact generates a constant state of stress among the workers. It is the stress of occupational character.

Illnesses arise when an individual's ability to respond to work in a healthy way is exhausted. Stress is recognized as one of the most serious risks to the individual's psychosocial well-being [11]. The work environment, too is a social variable, can be an important source of mental suffering. Workplace factors, related to the health-disease process, include noise, inadequate lighting, temperature extremes, vibration, aesthetics, hygiene and care. As factors related to work organization, overload or underload of physical and mental work; participation and involvement in work; interpersonal relationships at work; work pace and time pressure; making it impossible for functional ascension, due to the lack of implementation of job and salary plans [12]. Respiratory system diseases are the third major cause of absenteeism in the study. Respiratory diseases can be caused by the risk of aspiration of chemical and biological elements present in the work environment, or related to influenza, pneumonia or other respiratory disease. In 
addition, the team is susceptible and is constantly in contact with patients with diseases transmitted by droplets and aerosols and are not always diagnosed immediately [13]. That infectious and parasitic diseases, including bacterial food poisoning, infectious diarrhea and gastroenteritis, are considered to be preventable pathologies.

These may be associated with professional burnout, which undermines self-care. In most cases the onset of symptoms and the development of the disease are related to the ingestion of food or water contaminated with pathogenic microorganisms and /or their toxins. The occurrence of these pathologies suggests the fragility in hand hygiene among professionals, which increase the risks to their health and the health users under their care [14]. In relation to diseases of the digestive system, cardiovascular diseases, located in this study as diseases of the circulatory system, neoplasms and diseases related to low immunity, the nursing profession requires day and night work professionals in their work, which is characterized as an aggravating factor in the development of these diseases. In addition, the nursing profession allows more than one job to be accumulated; in some cases, workers accumulate up to three employment links [10]. That because of this intense working day, professionals have a greater habit of eating pre-cooked, frozen foods and also pinching. Some companies also do not care about the quality of the menu served, especially at night, including even feijoada for this population. With this, the complaints of the workers of heartburn, abdominal pains, constipation, are frequent, being able to aggravate and to arrive at cases of chronic gastritis or ulcers. Poor diet may favor the onset of digestive, cardiovascular, coronary and certain types of neoplasms [15]

\section{Conclusion}

Coming to the conclusion of this study, it can be concluded that the main diseases that led to absenteeism among nursing professionals were, according to the researched literature, musculoskeletal diseases, followed by mental disorders, diseases of the respiratory system, infectious and parasitic diseases and diseases of the digestive system. This survey confirmed that nursing staff, due to their work overload, long working hours, physical and mental exhaustion are contributing negatively to the incidence of these diseases and leading to absenteeism, especially in the number of medical licenses for musculoskeletal disorders and mental disorders

ISSN: 2574-1241

DOI: 10.26717/BJSTR.2019.16.002888

Bruno Vilas Boas Dias. Biomed J Sci \& Tech Res

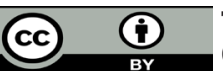

This work is licensed under Creative Commons Attribution 4.0 License

Submission Link: https://biomedres.us/submit-manuscript.php

\section{References}

1. Novaretti MCZ, Santos EV, Quitério LM, Daud Gallotti RM (2010) Sobrecarga de trabalho da Enfermagem e incidentes e eventos adversos em pacientes internados em UTI. Revista Brasileira de Enfermagem. 67(5): 692-699.

2. Formenton A, Mininel VA, Laus AM (2014) Absenteísmo por doença na equipe de enfermagem de uma operadora de plano de saúde. Revista de Enfermagem da UERJ 22(1): 42-49.

3. Aguiar GAS, Oliveira JR (2009) Absenteísmo: suas principais causas e consequências em uma empresa do ramo da saúde. Revista de Ciências Gerais 13(18): 95-113.

4. Sancinetti TR, Soares AVN, Lima AFC, Nanci Cristiano Santos, et al. (2011) Taxa de absenteísmo da equipe de enfermagem como indicador de gestão de pessoas. Rev Esc Enferm USP 45(4): 1007-1012.

5. Furlan JAS, Stancato K (2013) Fatores geradores do absenteísmo dos profissionais de enfermagem de um hospital público e um privado. Rev RAS 15(60): 112-120.

6. Brey C, Miranda FMD, Haeffner R, Ivandro Ribeiro dos Santos De Castro, Leila Maria Mansano Sarquis, et al. (2017) O absenteísmo entre os trabalhadores de saúde de um hospital público do sul do Brasil. Rev de Enfermagem do Centro Oeste Mineiro 7(1): 1-10.

7. Moisés CCS, Silva MG, Manhães FC, Istoe RSC (2014) Principais causas do absenteísmo em profissionais de enfermagem 4(2): 89-112.

8. Ribeiro DCM, Kuroba DS (2016) Fatores que levam os profissionais de enfermagem ao absenteísmo no Brasil. Caderno de Saúde e Desenvolvimento 9(5): 21-44.

9. Lucca SR, Rodrigues MSD (2015) Absenteísmo dos profissionais de enfermagem de um hospital universitário do estado de São Paulo, Brasil. Rev Bras Med Trab 13(2): 76-82

10. Galindo IS, Ferreira SCM, Lazzari DD (2017) Motivos do absenteísmo em uma equipe de enfermagem ambulatorial. Rev enferm UFPE online 11(8): 3198-205.

11. Marques DO, Pereira MS, Souza ACS (2015) 0 absenteísmo-doença da equipe de enfermagem de um hospital universitário. Rev Bras Enferm 68(5): 876-882

12. Rocha EL, Lima DMR (2000) Distúrbios psíquicos relacionados ao trabalho. In: Ferreira M Saúde no Trabalho: temas básicos para o profissional que cuida da saúde dos trabalhadores. São Paulo: Roca.

13. Mantovani VM, Nazareth JK, Maciel DNP, Biasibetti, Cecília, et al. (2015) Absenteísmo por enfermidade em profissionais de enfermagem. Rev Min. Enferm 19(3): 641-646.

14. Trindade LL, Grisa CC, Ostrovski VP (2014) Absenteísmo na equipe de enfermagem no ambiente hospitalar. Revista Enfermaria Global 36: 147155.

15. Santos CR, Santos RF, Machineski GG (2014) Qualidade do sono em profissionais que atuam no período noturno na assistência de enfermagem. Rev Thêma et Scientia 4(2): 165-172.s

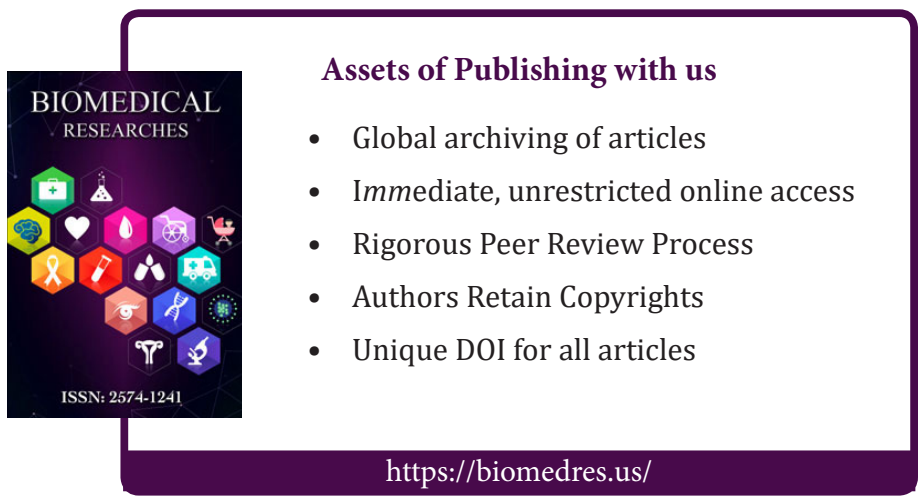

